\title{
Quantifying cell binding kinetics mediated by surface-bound blood type $B$ antigen to immobilized antibodies
}

\author{
LI BaoXia, CHEN Juan \& LONG Mian ${ }^{\dagger}$ \\ National Microgravity Laboratory and Center of Biomechanics and Bioengineering, Institute of Mechanics, Chinese Academy of \\ Sciences, Beijing 100190, China
}

Cell adhesion is crucial to many biological processes, such as inflammatory responses, tumor metastasis and thrombosis formation. Recently a commercial surface plasmon resonance (SPR)-based BIAcore biosensor has been extended to determine cell binding mediated by surface-bound biomolecular interactions. How such cell binding is quantitatively governed by kinetic rates and regulating factors, however, has been poorly understood. Here we developed a novel assay to determine the binding kinetics of surface-bound biomolecular interactions using a commercial BIAcore $\mathbf{3 0 0 0}$ biosensor. Human red blood cells (RBCs) presenting blood group B antigen and CM5 chip bearing immobilized anti-B monoclonal antibody (mAb) were used to obtain the time courses of response unit, or sensorgrams, when flowing RBCs over the chip surface. A cellular kinetic model was proposed to correlate the sensorgrams with kinetic rates. Impacts of regulating factors, such as cell concentration, flow duration and rate, antibody-presenting level, as well as $\mathrm{pH}$ value and osmotic pressure of suspending medium were tested systematically, which imparted the confidence that the approach can be applied to kinetic measurements of cell adhesion mediated by surface-bound biomolecular interactions. These results provided a new insight into quantifying cell binding using a commercial SPR-based BIAcore biosensor.

BIAcore biosensor, response unit, cellular kinetic model, cellular off-rate, cellular on-rate

A BIAcore biosensor is a surface plasmon resonance (SPR)-based commercial instrument to quantify the biomolecular interactions in real time. It measures the changes in the refractive index near a planar chip surface $(\leqslant \sim 300 \mathrm{~nm}$ from the surface) induced by binding of soluble molecules to immobilized counterpart molecules on the chip, and recorded time courses of response unit (RU), or sensorgrams, represent the number of bound molecules on the chip surface (c.f. Figure 1(a)). Nowadays it has become a widely-used conventional method in labs and in food and pharmaceutical industries for characterizing the kinetic rates and equilibrium affinity of antigen-antibody or receptor-ligand bindings in the fluidic phase $\mathrm{e}^{[1-3]}$. In the past decades, great efforts have been focused on obtaining accurate and reliable data, improving data analysis, and broadening the applications ${ }^{[4-9]}$.

SPR-based BIAcore biosensors are also able to be applied in determining the interactions of surface-bound biomolecules expressed on cells, bacteria or viruses, where no protein purification and/or reconstruction is required ${ }^{[10-18]}$. For example, bindings of human red blood cells (RBCs) expressing blood group antigens to immobilized anti-blood group specific antibodies (Abs)

\footnotetext{
Received June 5, 2008; accepted August 25, 2008 doi: 10.1007/s11434-008-0517-9

'Corresponding author (email: mlong@imech.ac.cn)

Supported by the High-Tech Research and Development Program of China (Grant No. 2007AA02Z306), National Basic Research Program of China (Grant No. 2006CB910303) and National Natural Science Foundation of China (Grant Nos. 30730032, 10332060, 30225027)
} 

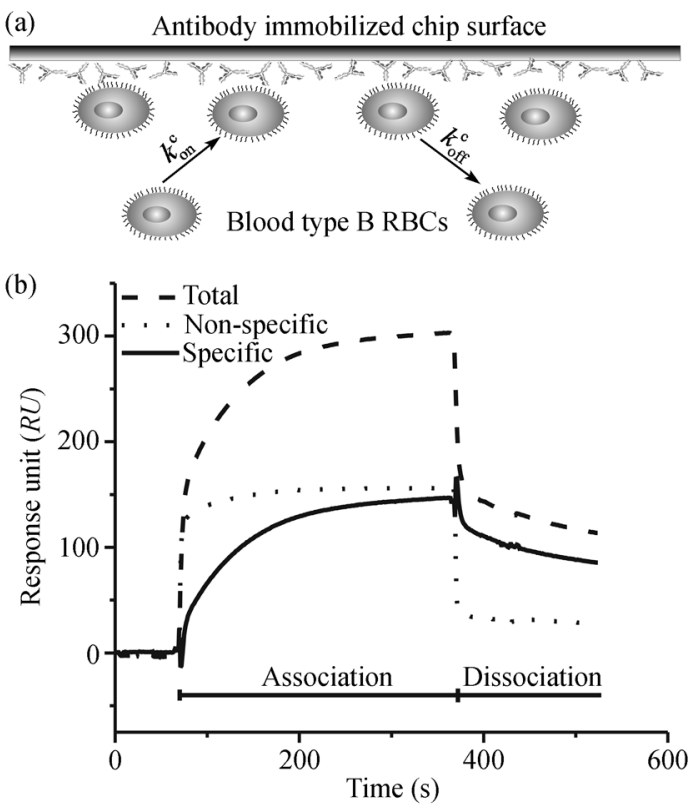

Figure 1 (a) Schematic of BIAcore cell binding assay. After being perfused into the flow chamber of a BIAcore biosensor, free blood type B RBCs will bind to and bound cells will debind from the anti-B antibody immobilized chip surface with reaction rates of $k_{\text {off }}^{\mathrm{c}}$ and $k_{\mathrm{on}}^{\mathrm{c}}$. (b) Cell binding specificity. Response units for specific binding of blood group B antigen and anti-B antibody interactions (solid line) are obtained by subtracting non-specific binding of blood type B RBCs to the plain chip surface (dotted line) from total binding of RBCs to the anti-B mAb-immobilized chip surface (dashed line).

on a chip surface were measured to sort blood group specific RBCs from whole blood samples ${ }^{[11,12]}$. Similar measurements were conducted to identify the novel monoclonal antibodies (mAbs) for virulent Listeria monocytogenes cells $\frac{[13-15]}{}$, to map the peptide ligands selectively capturing circulating malignant epithelial cells from human prostate, bladder and breast cancer cells ${ }^{[16]}$, to characterize the binding epitopes of plasmodium vivax domain that adheres Duffy antigen in RBC invasion $^{[17]}$, to determine the valency of antibody binding to the enveloped human influenza virus particles ${ }^{[18]}$, and to quantify the binding of staphylococcus aureus and staphylococcus epidermidis cells to immobilized fibronectin ${ }^{[10]}$. Although these pioneering works provide potential possibilities to extend the SPR-based BIAcore biosensor in measuring biomolecular interactions on cellular surface, quantitative analysis on kinetic rates and binding affinity remains to be poorly known. Cautions should also be taken when one uses the same kinetic model as those used in fluidic phases to predict the kinetic parameters, since bindings of flowing cells bearing the molecules of interest to immobilized counterpart molecules on a chip surface are governed by kinetic rates and binding affinity of interacting molecules, biomolecular site densities, cell concentration, flow rate and duration, as well as physical-chemical environments.

Recently, we developed a cellular kinetic model and relevant experimental procedures and data analysis to quantify the kinetics of cellular binding mediated by the surface-bound molecular specific interaction using SPR technique ${ }^{[19]}$. Here this new approach was applied to determining the binding kinetics of RBCs expressing blood group $\mathrm{B}$ antigens to the chip surface bearing anti-B mAbs. And the impacts of antibody-presenting level, cell concentration, flow rate and duration, as well as medium $\mathrm{pH}$ value and osmotic pressure on cellular binding were systematically tested.

\section{Materials and methods}

\subsection{RBCs preparation}

Blood type B RBCs, determined using conventional ABO blood type test (www. Bloodbook.com) ${ }^{[20]}$, were isolated from fresh whole blood. The cells were stored at $4{ }^{\circ} \mathrm{C}$ in EAS45+ solution ${ }^{[21,22]}$ after being washed two times in phosphate buffer (PBS) and two times in EAS45+. All cells were obtained from a single healthy donor to have the stable site density of blood group B antigen on cell surface.

In some measurements, $\mathrm{H}_{2} \mathrm{O}$ and EAS45+ were mixed at $v / v$ ratio of $1: 1,1: 1.4,1: 2$, and $0: 1$ to obtain mixtures of 150, 175, 200 and 300 mOsm osmotic pressure. The mixture was used as suspending medium just before RBC suspension was perfused over the anti-B $\mathrm{mAb}$ immobilized chip surface. In other measurements, the $\mathrm{pH}$ value of EAS45+ was adjusted to 6.0, 6.7, 7.4 and 8.1 with $1 \mathrm{~mol} / \mathrm{L} \mathrm{NaOH}$ or $\mathrm{HCl}$, and then the cells were suspended in the medium less than 5 min before perfusion.

\subsection{BIAcore cell assay}

All cell assays were performed using BIAcore $3000^{\mathrm{TM}}$ biosensor (Pharmacia, Sweden) at $25^{\circ} \mathrm{C}$ on CM5 chip with PBS and EAS45+ as respective running and working buffers. $10 \mu \mathrm{g} / \mathrm{mL}$ mouse anti-human B mAbs in $10 \mathrm{mM}$ sodium acetate $(\mathrm{pH}=4.5)$ (Sigma, USA) was immobilized onto CM5 chip surface using the standard amine coupling method. Two specific chip surfaces were obtained at antibody-presenting levels of 6000 and 11800 RU. One plain chip surface with the same activation and 
de-activation treatments as a specific surface but without protein immobilization was used as a control surface.

In BIAcore cell assay, RBC suspension was perfused to flow over on and bind to the chip surface at the pre-set flow rate and duration, the so-called association phase. At the endpoint of the association phase, PBS was perfused to de-bind bound cells from the chip surface, the so-called dissociation phase (Figure 1(b)). Time courses of cell binding responses (RU) were obtained in real time from the measurements. The chip surface was then regenerated by perfusing PBS by applying a long ( $>$ $30 \mathrm{~min}$ ) and quick (>50 $\mu \mathrm{L} / \mathrm{min}$ ) flow. Such an association-dissociation-regeneration cycle was repeated in triplicate at each condition.

\subsection{Data analysis}

Measured sensorgrams of RBCs' binding to and debinding from the mAb-immobilized chip surface were analyzed using a newly-developed cellular kinetic model ${ }^{[19]}$. Upon the assumptions that proteins are uniformly distributed on respective cell and chip surfaces, that binding of a cell to one region of chip surface does not affect the ability of another cell to adhere to another region, that the interaction among cells is neglected, and that detached cells no longer re-bind onto the chip surface, the specific cell binding response, $\mathrm{RU}(t)$, follows during the association phase ${ }^{[19]}$ :

$$
\begin{aligned}
\mathrm{RU}(t) & =\frac{k_{\mathrm{on}}^{\mathrm{c}} \times C \times \mathrm{RU}_{\max }}{k_{\text {on }}^{\mathrm{c}} \times C+k_{\text {off }}^{\mathrm{c}}}\left\{1-\exp \left[-\left(k_{\mathrm{on}}^{\mathrm{c}} \times C+k_{\text {off }}^{\mathrm{c}}\right) t\right]\right\} \\
& =\frac{K_{\mathrm{on}}^{\mathrm{c}} \times \mathrm{RU}_{\max }}{K_{\text {on }}^{\mathrm{c}}+k_{\text {off }}^{\mathrm{c}}}\left\{1-\exp \left[-\left(K_{\text {on }}^{\mathrm{c}}+k_{\text {off }}^{\mathrm{c}}\right) t\right]\right\},
\end{aligned}
$$

or during the dissociation phase ${ }^{[19]}$

$$
\mathrm{RU}(t)=\mathrm{RU}^{p} \times \exp \left(-k_{\mathrm{off}}^{\mathrm{c}} t\right),
$$

where $t$ is the time duration for RBC and PBS perfusion in eqs. (1) and (2), respectively, $k_{\mathrm{on}}^{\mathrm{c}}$ (in $\mathrm{mL} / \mathrm{s}$ ) and $k_{\mathrm{off}}^{\mathrm{c}}$ $\left(\right.$ in s ${ }^{-1}$ ) are the on- and off-rates per cell, $C$ is the free cell concentration close to the chip, and $\mathrm{RU}_{\max }$ is the maximum cell binding response physically available at a given chip surface. The effective on-rate, $K_{\mathrm{on}}^{\mathrm{c}}\left(=k_{\mathrm{on}}^{\mathrm{c}} \times C\right)$ (in $\mathrm{s}^{-1}$ ), is used to define the bulk association reaction. To predict the kinetic parameters of cell binding, eqs. (1) and (2) are used to fit the data obtained from association and dissociation phases, respectively. This returns a set of lumped binding rate, $K_{\mathrm{b}}^{\mathrm{c}}\left(=K_{\mathrm{on}}^{\mathrm{c}}+k_{\mathrm{off}}^{\mathrm{c}}\right)$, and the off-rate per cell, $k_{\text {off }}^{\mathrm{c}}$, and the effective on-rate, $K_{\text {on }}^{\mathrm{c}}$, is calculated as $K_{\mathrm{b}}^{\mathrm{c}}-k_{\text {off }}^{\mathrm{c}}$.

In some cases, peak $\mathrm{RU}^{P}$ or $\mathrm{RU}^{P}$, the response at the endpoint of the association phase, is used to represent the amount of bound cells. One-way analysis of variances (one-way ANOVA) was conducted to determine if $\mathrm{RU}^{P}$ was statistically different with a systematicallyvaried regulating factor. The statistical significance of the difference between $\mathrm{RU}^{P}$ values at different levels of the factor was then assessed with $P$ value obtained by multiple comparisons, Duncan-test.

\section{Results}

\subsection{Cell binding was specifically mediated}

Binding of blood type B RBCs to the anti-B mAb-immobilized chip surface was determined using the time course of response unit, $\mathrm{RU}(t)$. To subtract the non-specific response on a plain surface from the total response on a specific surface, cell suspension was flowed over plain and specific chip surfaces serially. As exemplified in Figure 1(b), RU was significantly higher when both blood group B antigens and anti-B mAbs were present (dashed line) than that when anti-B mAbs were absent (dotted line). The time course of a specific response (solid line) was then obtained by subtracting the non-specific response from the total response. These data demonstrated that cell bindings measured using a SPR-based BIAcore 3000 biosensor were specifically mediated by blood group B antigen-anti-BSA mAb interactions. Moreover, repeated tests at the same condition produced the highly-reproductive $\mathrm{RU}(t)$, confirming the robustness of the assay (data not shown).

\subsection{Cell binding was regulated by cell concentration and antibody-presenting level}

Cell binding varies with cell concentration and antibody-presenting level upon mass transport law. To test this, cell concentration was systematically varied at $4 \times 10^{7}, 8 \times 10^{7}, 20 \times 10^{7}$ and $40 \times 10^{7}$ cells $/ \mathrm{mL}$ at a given flow duration of $10 \mathrm{~min}$ and flow rate of $5 \mu \mathrm{L} / \mathrm{min}$ when both high $\left(m_{l 1}=11800 \mathrm{RU}\right)$ and low $\left(m_{l 2}=6000 \mathrm{RU}\right)$ antibody-presenting levels were used. As exemplified in Figure 2, $\mathrm{RU}^{P}$ was significantly enhanced with increased cell concentration at a given antibody-presenting level, indicating that cell binding follows the mass transport law.

Cellular kinetic parameters, obtained from fitting measured sensorgrams using eqs. (1) and (2), were fur- 
ther compared at varied cell concentrations at $m_{l 2}=6000$ RU. As exemplified in Figure 3, the lumped binding rate $K_{\mathrm{b}}^{\mathrm{c}}$, off-rate per cell $k_{\text {off }}^{\mathrm{c}}$ and effective binding rate $K_{\text {on }}^{\mathrm{c}}\left(=K_{\mathrm{b}}^{\mathrm{c}}-k_{\text {off }}^{\mathrm{c}}\right)$ were 4.7-, 7.7- and 3.5-fold lower, respectively, when cell concentration was increasing from $4 \times 10^{7}$ to $40 \times 10^{7}$ cells $/ \mathrm{mL}$. This reduced dependence of cellular kinetic rates should not be surprised because strong interactions between flowing and/or bound cells are no longer neglected at high cell concentration, which would inhibit the binding of free flowing cells at the late association phase. The impact of cell-cell interactions on cell binding was further observed when a high antibody-presenting level ( $\left.m_{l 1}=11800 \mathrm{RU}\right)$ was used, where

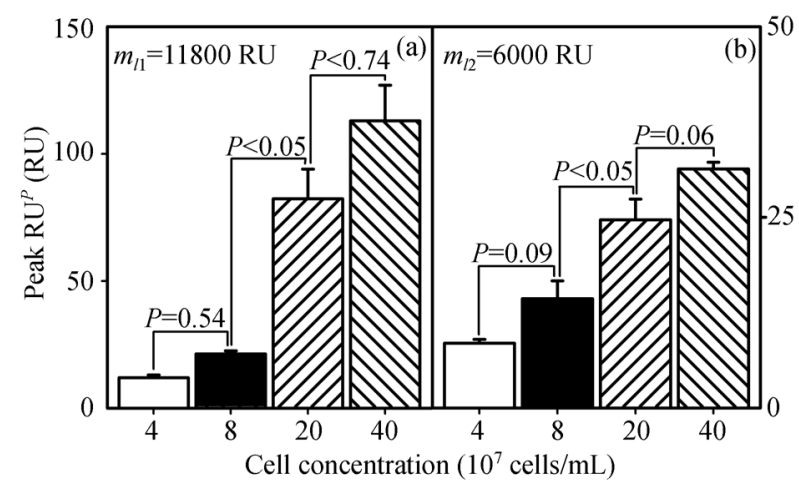

Figure 2 Dependence of cell concentration. Peak $\mathrm{RU}^{P}$ is plotted at $4 \times 10^{7}$ (open bars), $8 \times 10^{7}$ (closed bars), $20 \times 10^{7}$ (leftwards-hatched bars) and $40 \times 10^{7}$ (rightwards-hatched bars) cells $/ \mathrm{mL}$, respectively, at a flow rate of $5 \mu \mathrm{L} / \mathrm{min}$ and flow duration of $10 \mathrm{~min}$ at respective $m_{l 1}$ (a) and $m_{l 2}$ (b). Data are presented as the mean \pm standard error (SE) of peak $\mathrm{RU}^{P}$ for three test cycles at that condition. $P$ value indicates the level of statistical significance of differences in peak $\mathrm{RU}^{P}$ at different cell concentrations.

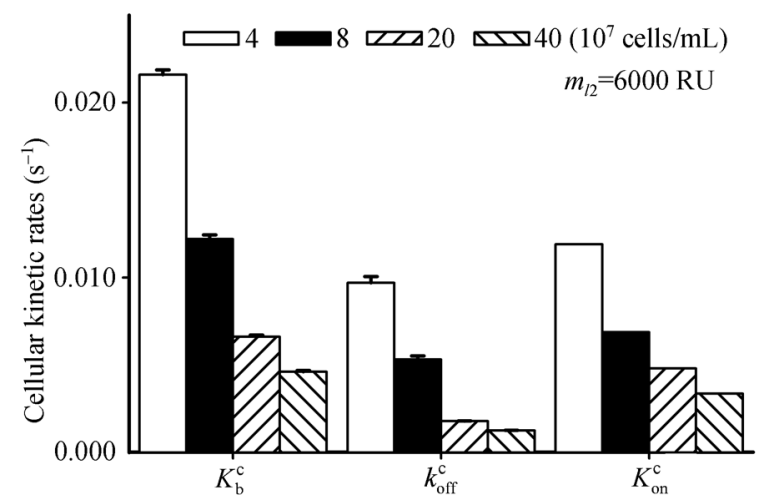

Figure 3 Dependence of cellular kinetic rates on cell concentration at $m_{l 2}=6000 \mathrm{RU}$ at a flow rate of $5 \mu \mathrm{L} / \mathrm{min}$ and flow duration of $10 \mathrm{~min}$. The lumped binding rate, $K_{\mathrm{b}}^{\mathrm{c}}$, and off-rate per cell, $k_{\text {off }}^{\mathrm{c}}$, were obtained by fitting the measured sensorgrams using eqs. (1) and (2) at cell concentration of $4 \times 10^{7}$ (open bars), $8 \times 10^{7}$ (closed bars), $20 \times 10^{7}$ (leftwards-hatched bars) and $40 \times 10^{7}$ (rightwards-hatched bars) cells $/ \mathrm{mL}$, respectively. The effective on-rate, $K_{\mathrm{on}}^{\mathrm{c}}$, was calculated as $K_{\mathrm{b}}^{\mathrm{c}}-k_{\mathrm{off}}^{\mathrm{c}}$. measured sensorgrams were no longer stable and no reasonable fitting could be obtained (data not shown). Noting that the low cell-cell interactions and high measuring sensitivity should be balanced, a moderate cell concentration of $20 \times 10^{7}$ cells $/ \mathrm{mL}$ was selected here for the following measurements.

\subsection{Flow duration did not influence cell binding}

To test the impact of flow duration on cell binding, the measurements were conducted at systematically-varied flow durations of 10,15 and $20 \mathrm{~min}$, at a given flow rate of $5 \mu \mathrm{L} / \mathrm{min}$. As exemplified in Figure 4, the average $\mathrm{RU}^{P}$ at $m_{l 1}=11800 \mathrm{RU}$ was similar at flow durations of 5 and 10 min (Figure 4(a), $P=0.78$ ) but slightly higher at the duration of $20 \mathrm{~min}$ (Figure 4(a), $P=0.06$ ). No statistically-significant differences in $\mathrm{RU}^{P}$ were found for three durations at $m_{l 2}=6000 \mathrm{RU}$ (Figure 4(b), $P=$ 0.19 ). These data indicated that $\mathrm{RU}^{P}$ was regulated by flow duration at high, but not low, antibody-presenting level, suggesting that cell binding tends to reach the equilibrium at a low antibody-presenting level. At the same flow duration, $\mathrm{RU}^{P}$ increased with the increasing antibody-presenting level, further supporting that cell binding follows the mass transport law.

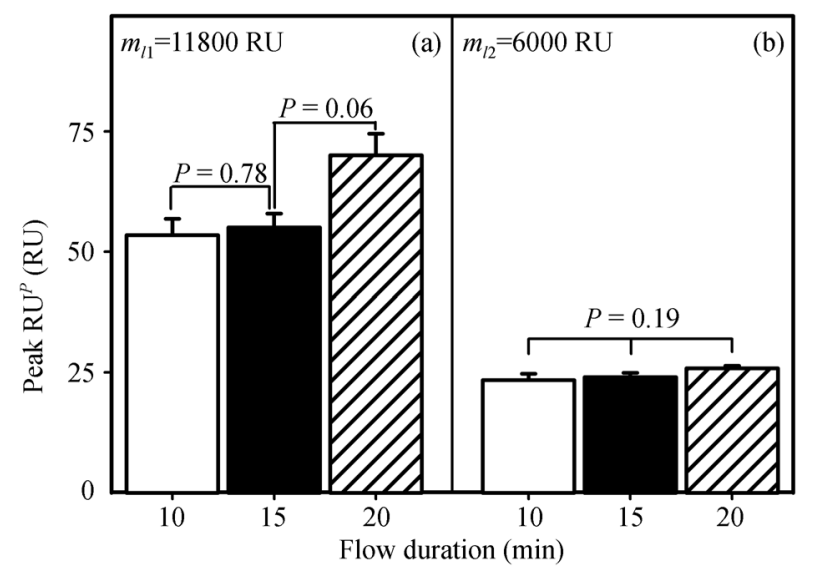

Figure 4 Dependence of flow duration. Peak $\mathrm{RU}^{P}$ is plotted at $10 \mathrm{~min}$ (open bars), $15 \mathrm{~min}$ (closed bars) and $20 \mathrm{~min}$ (leftwards-hatched bars), respectively, at cell concentration of $20 \times 10^{7}$ cells $/ \mathrm{mL}$ and flow rate of 5 $\mu \mathrm{L} /$ min at respective $m_{l 1}$ (panel a) and $m_{l 2}$ (panel b). Data are presented as the mean $\pm \mathrm{SE}$ of peak $\mathrm{RU}^{P}$ for three test cycles at that condition. $P$ value indicates the level of statistical significance of differences in peak $\mathrm{RU}^{P}$ at different flow durations.

Effect of flow duration on cellular kinetic parameters was tested using both individual and global fittings at $m_{l 1}=11800 \mathrm{RU}^{[19]}$. In an individual fitting, the data for the three test cycles at a given flow duration were pooled and then fitted using eqs. (1) and (2) to predict 
kinetic parameters at that duration. As exemplified in Figure 5(a), no significant differences in kinetic parameters were found at $10 \mathrm{~min}$ (open bars), $15 \mathrm{~min}$ (solid bars), and $20 \mathrm{~min}$ (leftwards-hatched bars). This was further observed by a global fitting, where the data for all nine test cycles at three flow durations were pooled together and fitted using a single set of parameters. The mean averages of those obtained from individual fittings at three flow durations $K_{\mathrm{b}}^{\mathrm{c}}=2.8 \times 10^{-3} \mathrm{~s}^{-1}$ and $k_{\text {off }}^{\mathrm{c}}=$ $4.2 \times 10^{-4} \mathrm{~s}^{-1}$ (rightwards-hatched bars), were in excellent agreement with the global fitting returned kinetic parameters $\left(K_{\mathrm{b}}^{\mathrm{c}}=2.3 \times 10^{-3}\right.$ and $\left.k_{\text {off }}^{\mathrm{c}}=4.0 \times 10^{-4} \mathrm{~s}^{-1}\right)$ (crossed bars). This agreement was also observed in calculated effective on-rate $K_{\mathrm{on}}^{\mathrm{c}}\left(2.3 \times 10^{-3}\right.$ and $\left.1.9 \times 10^{-3} \mathrm{~s}^{-1}\right)$ (Figure 5(a)). Similar results were obtained at $m_{l 2}=6000$

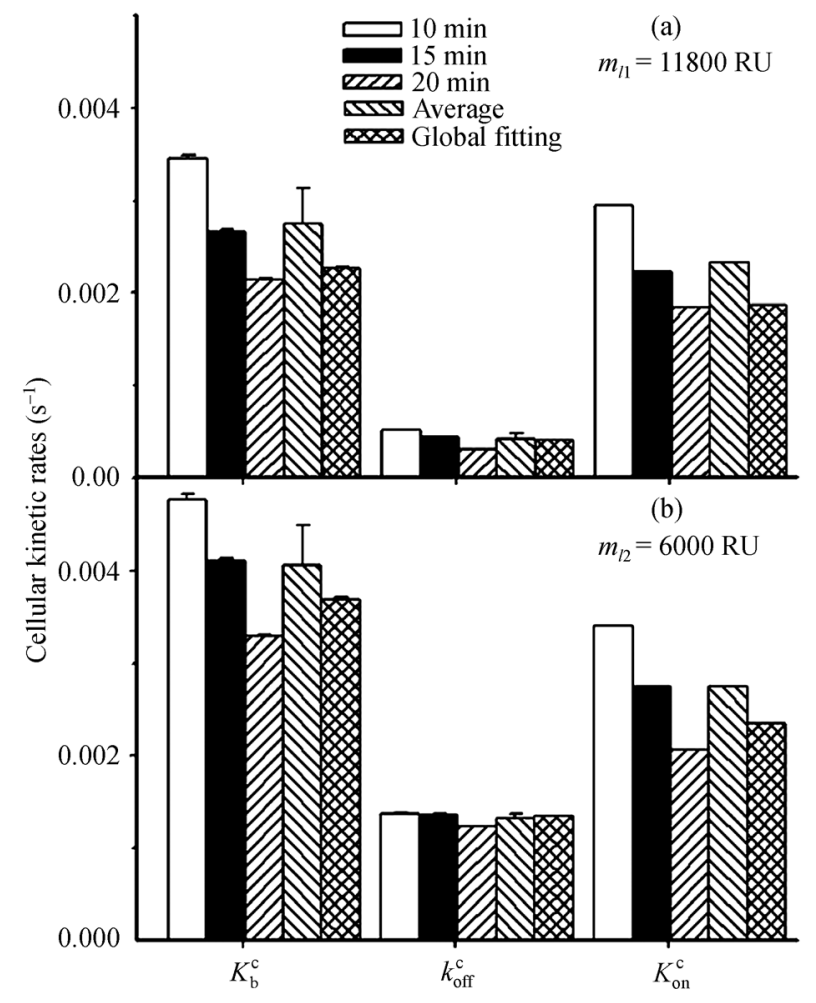

Figure 5 Dependence of cellular kinetic rates on flow duration at the cell concentration of $20 \times 10^{7}$ cells $/ \mathrm{mL}$ and flow rate of $5 \mu \mathrm{L} / \mathrm{min}$ at respective $m_{l 1}$ (panel a) and $m_{l 2}$ (panel b). The lumped binding rate, $K_{\mathrm{b}}^{\mathrm{c}}$, and off-rate per cell, $k_{\text {off }}^{\mathrm{c}}$, were obtained by fitting the measured sensorgrams individually at $10 \mathrm{~min}$ (open bars), $15 \mathrm{~min}$ (closed bars) and $20 \mathrm{~min}$ (leftwards-hatched bars). Also plotted are the mean values by averaging these three sets of parameters predicted from individual fitting at each flow duration (rightwards-hatched bars) and the single set of parameters from global fitting at all three flow durations (crossed bars). The effective on-rate, $K_{\text {on }}^{\mathrm{c}}$, was calculated as $K_{\mathrm{b}}^{\mathrm{c}}-k_{\text {off }}^{\mathrm{c}}$.
RU (Figure 5(b)). Taken together, these results indicated that flow duration did not affect cellular binding kinetics.

\subsection{Flow rate affected cell binding}

To test the impact of the flow rate on cell binding, the measurements were done at the systematically varied flow rate of 1,5 and $10 \mu \mathrm{L} / \mathrm{min}$, respectively, at a given flow duration of $10 \mathrm{~min}$. As exemplified in Figure 6, $\mathrm{RU}^{P}$ at $m_{l 1}=11800 \mathrm{RU}$ increased dramatically with the flow rate from $1 \mu \mathrm{L} / \mathrm{min}$ (open bar) to $5 \mu \mathrm{L} / \mathrm{min}$ (closed bar) (Figure 6(a), $P=0.07$ ) but less significantly from 5 $\mu \mathrm{L} / \mathrm{min}$ to $10 \mu \mathrm{L} / \mathrm{min}$ (leftwards-hatched bar) (Figure 6(a), $P=0.21$ ), while statistically-significant differences in $\mathrm{RU}^{P}$ were found for three rates at $m_{l 2}=6000 \mathrm{RU}$ (Figure 6(b), $P=0.05$ ). These data indicated that $\mathrm{RU}^{P}$ was regulated by the flow rate, imparting the confidence that cell binding tends to reach the equilibrium with the flow rate. At the same flow rate, $\mathrm{RU}^{P}$ was enhanced with the antibody-presenting level from lower $m_{l 2}$ (Figure 6(b)) to higher $m_{l 1}$ (Figure 6(a)).

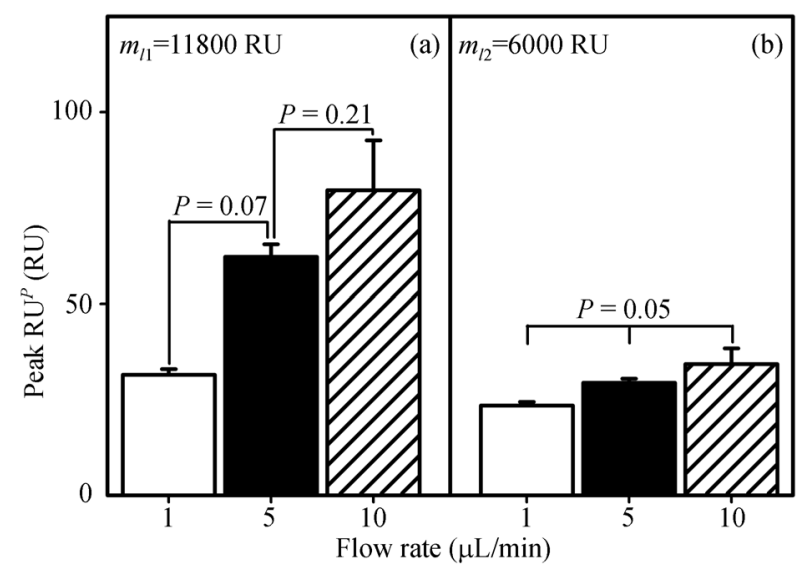

Figure 6 Dependence of flow rate. Peak $\mathrm{RU}^{P}$ is plotted at $1 \mu \mathrm{L} / \mathrm{min}$ (open bars), $5 \mu \mathrm{L} / \mathrm{min}$ (closed bars) and $10 \mu \mathrm{L} / \mathrm{min}$ (leftwards-hatched bars), respectively, at the cell concentration of $20 \times 10^{7}$ cells $/ \mathrm{mL}$ and flow duration of $10 \mathrm{~min}$ at respective $m_{l 1}$ (panel a) and $m_{l 2}$ (panel b). Data are presented as the mean $\pm \mathrm{SE}$ of peak $\mathrm{RU}^{P}$ for three test cycles at that condition. $P$ value indicates the level of statistical significance of differences in peak $\mathrm{RU}^{P}$ at different flow rates.

Impact of the flow rate on cell binding was further tested by comparing the kinetic parameters. As exemplified in Figure 7(a), $K_{\mathrm{b}}^{\mathrm{c}}$ was 3.2- and 3.9-fold lower, $k_{\text {off }}^{\mathrm{c}}$ was 2.3- and 2.1-fold higher, and $K_{\mathrm{on}}^{\mathrm{c}}$ was 10.1and 12.4-fold lower at $1 \mu \mathrm{L} / \mathrm{min}$ (open bars) than those at $5 \mu \mathrm{L} / \mathrm{min}$ (closed bars) and $10 \mu \mathrm{L} / \mathrm{min}$ (leftwardshatched bars $)\left(K_{\mathrm{b}}^{\mathrm{c}}=1.2 \times 10^{-3}, 3.8 \times 10^{-3}\right.$ and $4.7 \times 10^{-3} \mathrm{~s}^{-1}$, 
$k_{\text {off }}^{\mathrm{c}}=0.85 \times 10^{-3}, \quad 0.37 \times 10^{-3}$ and $0.40 \times 10^{-3} \mathrm{~s}^{-1}$, and $K_{\mathrm{on}}^{\mathrm{c}}=0.3 \times 10^{-3}, 3.4 \times 10^{-3}$ and $4.2 \times 10^{-3} \mathrm{~s}^{-1}$, respectively) at $m_{l 1}=11800 \mathrm{RU}$. Similar results with the less magnitude differences were obtained at $m_{l 2}=6000 \mathrm{RU}$ (Figure 7(b)). Taken together, these results suggested that the flow rate regulated the cell binding kinetics.

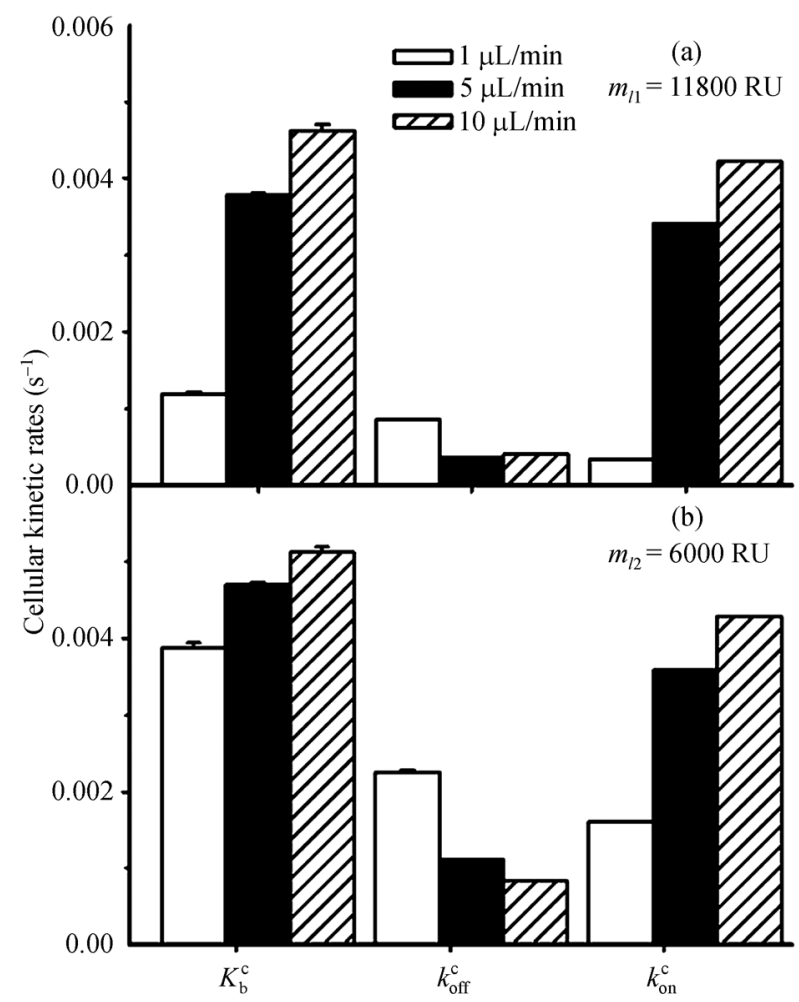

Figure 7 Dependence of cellular kinetic rates on flow rate at the cell concentration of $20 \times 10^{7}$ cells $/ \mathrm{mL}$ and flow duration of $10 \mathrm{~min}$ at respective $m_{l 1}$ (panel a) and $m_{l 2}$ (panel b). The lumped binding rate, $K_{\mathrm{b}}^{\mathrm{c}}$, and off-rate per cell, $k_{\text {off }}^{\mathrm{c}}$, were obtained by fitting the measured sensorgrams at $1 \mu \mathrm{L} / \mathrm{min}$ (open bars), $5 \mu \mathrm{L} / \mathrm{min}$ (closed bars) and $10 \mu \mathrm{L} / \mathrm{min}$ (leftwards-hatched bars).

\subsection{Cell binding was correlated with medium $\mathrm{pH}$ value and osmotic pressure}

To understand the effect of physical-chemical environment on cell binding, blood type B RBCs were suspended in the systematically varied $\mathrm{pH}$ value of suspending medium, and cell binding measurements were performed using the new approach. As exemplified in Figure $8, \mathrm{RU}^{P}$ was reduced by 12 - and 2.3 -fold at respective $m_{l 1}=11800$ and $m_{l 2}=6000 \mathrm{RU}(P<0.05)$ when the medium $\mathrm{pH}$ value was enhanced from 6.0 to 8.1 , indicating that the acidity of suspending medium significantly affected the cell binding. Since RBC mem- brane and dextran matrix on CM5 chip surface were negatively charged at $\mathrm{pH}=7.4^{[23]}$ and at $\mathrm{pH}>3.5$, respectively, the electrostatic repulsion between $\mathrm{RBC}$ and matrix was strengthened with the increased $\mathrm{pH}$ value, which in turn inhibited cell binding at a higher $\mathrm{pH}$.

To further test the effect, cell binding was measured at a medium osmotic pressure of 150, 175, 200 and 300 mOsm. $\mathrm{RU}^{P}$ at $m_{l 2}=6000 \mathrm{RU}$ was enhanced with increased osmotic pressure and then reached the maximum value at a physiological osmotic pressure of $300 \mathrm{mOsm}$

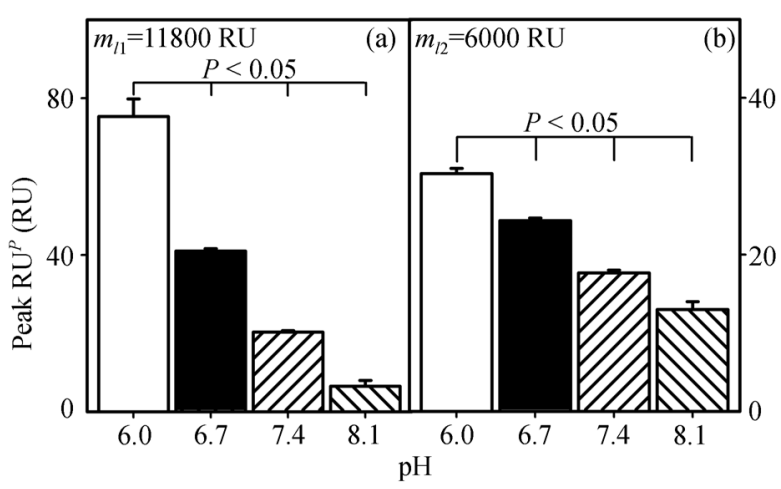

Figure 8 Dependence of $\mathrm{pH}$ value of cell suspension. Peak $\mathrm{RU}^{P}$ is plotted at $\mathrm{pH} 6.0$ (open bars), $\mathrm{pH} 6.7$ (closed bars), $\mathrm{pH} 7.4$ (leftwards-hatched bars) and $\mathrm{pH} 8.1$ (rightwards-hatched bars), respectively, at the cell concentration of $20 \times 10^{7}$ cells $/ \mathrm{mL}$, flow duration of $10 \mathrm{~min}$, and flow rate of 5 $\mu \mathrm{L} /$ min at respective $m_{l 1}$ (panel a) and $m_{l 2}$ (panel b). Data are presented as the mean $\pm \mathrm{SE}$ of peak $\mathrm{RU}^{P}$ for three test cycles at that condition. $P$ value indicates the level of statistical significance of differences in peak $\mathrm{RU}^{P}$ at different $\mathrm{pH}$ values.

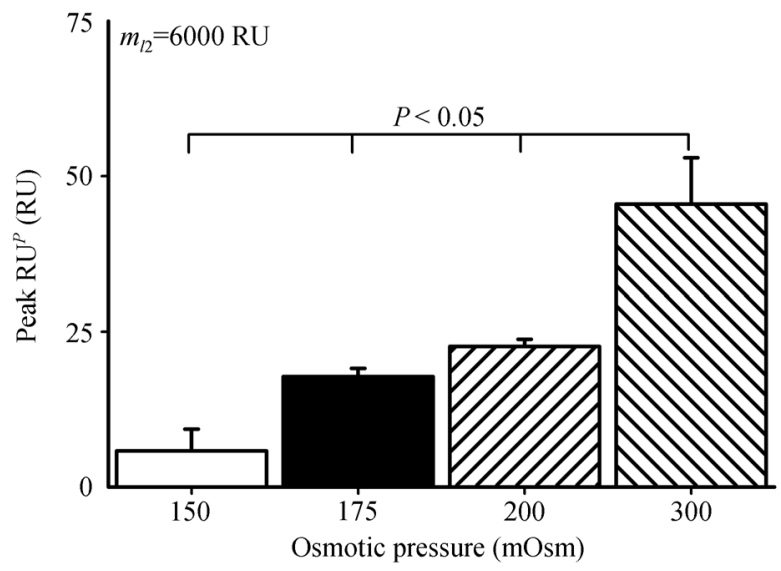

Figure 9 Dependence of osmotic pressure of cell suspension. Peak $\mathrm{RU}^{P}$ is plotted at $150 \mathrm{mOsm}$ (open bars), $175 \mathrm{mOsm}$ (closed bars), $200 \mathrm{mOsm}$ (leftwards-hatched bars) and $300 \mathrm{mOsm}$ (rightwards-hatched bars), respectively, at the cell concentration of $20 \times 10^{7}$ cells $/ \mathrm{mL}$, flow duration of $10 \mathrm{~min}$, and flow rate of $5 \mu \mathrm{L} / \mathrm{min}$ at $m_{l 1}$. Data are presented as the mean \pm $\mathrm{SE}$ of peak $\mathrm{RU}^{P}$ for three test cycles at that condition. $P$ value indicates the level of statistical significance of differences in peak $\mathrm{RU}^{P}$ at different osmotic pressures. 
(Figure 9, $P<0.05$ ). As the osmotic pressure increased from 150 to $300 \mathrm{mOsm}, \mathrm{RBC}$ 's shape was changed from sphericity to biconcave disc (data not shown), which enhanced the effective contact area of RBCs to the surface and in turn the response per bound cell ${ }^{[12]}$. Effective peak $\mathrm{RU}^{P}$ at $m_{l 1}=11800 \mathrm{RU}$, however, was not obtained, mainly because the cell binding was no longer stable especially at low osmotic pressures.

\section{Discussion}

Interactions of surface-bound biomolecules are governed by their binding kinetics as well as by physical-chemical regulating factors. Upon the developed cellular kinetic model and the proposed assay using a SPR-based BIAcore biosensor, the time course of cell binding was able to be correlated with cellular kinetic rates. Impacts of the antibody-presenting level and cell concentration, flow duration and rate, as well as medium $\mathrm{pH}$ value and osmotic pressure were tested to further understand the cellular binding kinetics (Figrues 2-9). The advantage of the new approach is to extend SPR technique from soluble analytes into surface-bound biomolecules with quantified kinetic rates. Such a new approach also provides a functional cell binding platform in pharmaceutical industries.

The kinetic model developed here was based on Langmuir equations from bulk chemistry ${ }^{[3,24]}$. To extend the model to predict cell binding mediated by surfacebound biomolecular interactions, two important issues, cell transport and cell-cell interactions, should be taken into account carefully. Unlike the soluble biomolecular kinetics measurements where mass transport effect is minimized using a high flow rate $(>30 \mu \mathrm{L} / \mathrm{min})$ and low antibody-presenting level (about several hundreds of $\mathrm{RU})^{[4,24-26]}$, a high antibody-presenting level (about several thousands of RU or even higher) and low flow rate $(1-10 \mu \mathrm{L} / \mathrm{min})$ are required in the current cell binding assay to enable the binding of RBCs to immobilized mAbs at a measurable sensitivity. Besides, cell concentration should be carefully determined in order to have the high sensitivity but the low interactions among free and/or bound cells, because high cell concentration would significantly bias the time courses of cell binding which in turn prevent estimating the kinetic rates from fitting the sensorgrams (Figure 3). Prediction of spatial and temporal distribution of flowing cells at the vicinity of chip surface, $C$, from a high bulk cell concentration (e.g. $20 \times 10^{7}$ cells $/ \mathrm{mL}$ ) is still a challenge even in fluid mechanics analysis, which is beyond the scope of the current work.

The prerequisite for use of the above equations to predict the measured sensorgrams is the linear relationship between measured RU and the number of bound cells. This seems to be reasonable when no significant cell transport and cell-cell interactions are found in cell binding ${ }^{[12,16,26]}$. To understand the mechanism regulating cell binding, impacts of cell concentration, flow duration and rate, and medium $\mathrm{pH}$ value and osmotic pressure were tested experimentally in the current work (Figures $2-9$ ), and our data indicated that the approach is applicable to surface-bound biomolecules constitutively-expressed on RBC or immobilized on a chip surface. This new approach is able to be applied in other biological systems where interacting molecules are surface-bound. It should be pointed out, however, that such dependences of regulating factors vary with the identities of cells and biomolecules of interest.

The cellular kinetic rates reported here are different from the molecular kinetic rates of surface-bound biomolecular interactions. This is because the binding of soluble or cell-bound antigens (or receptor) to immobilized antibodies (or ligand) is governed by respective kinetic mechanisms. In a typical measurement as performed in a conventional BIAcore test for soluble analytes, mass transport effect must be taken into account to best fit sensorgram data at varied analyte concentrations and probe site densities when the reaction kinetic model in bulk chemistry is applied ${ }^{[27-29]}$. In the measurement for surfacebound molecules reported, however, a probabilistic model is required because the binding of a cell-bound antigen (or receptor) to an immobilized antibody (or ligand) is a stochastic process and governed by two-dimensional kinetics of small systems ${ }^{[29-38]}$. Here a cellular kinetic model was proposed, as the first step of serial studies, to correlate cell binding responses to cellular kinetic rates and to develop a relevant assay for experimental measurements and data analysis. A new kinetic model accounting for spatial and temporal distribution of flowing cells at the vicinity of chip surface is required in future investigating the intrinsic kinetic rates of surface-bound molecules from measured sensorgrams.

We thank Dr. George F. Gao and Ms. Zheng Fan from Institute of Microbiology, Chinese Academy of Sciences, for providing BIAcore 3000 biosensor and technical assistances. We also thank Dr. Cheng Zhu from Georgia Institute of Technology for helpful discussions. 
1 Karlsson R, Fagerstam L, Nilshans H, et al. Analysis of active antibody concentration separation of affinity and concentration parameters. J Immunol Methods, 1993, 166: 75-84[doi]

2 Karlsson R, Falt A. Experimental design for kinetic analysis of protein-protein interactions with surface plasmon resonance biosensors. $\mathrm{J}$ Immunol Methods, 1997, 200: 121-133[doi]

3 Karlsson R, Michaelsson A, Mattsson L. Kinetic analysis of monoclonal antibody-antigen interactions with a new biosensor based analytical system. J Immunol Methods, 1991, 145: 229-240[doi]

4 Day Y S, Baird C L, Rich R L, et al. Direct comparison of binding equilibrium, thermodynamic, and rate constants determined by surface- and solution-based biophysical methods. Protein Sci, 2002, 11: 1017-1025[doi]

5 Dahlin A B, Tegenfeldt J O, Hook F. Improving the instrumental resolution of sensors based on localized surface plasmon resonance. Anal Chem, 2006, 78: 4416-4423[doi]

6 Dillon P P, Killard A J, Daly S J, et al. Novel assay format permitting the prolonged use of regeneration-based sensor chip technology. J Immunol Methods, 2005, 296: 77-82[doi]

7 Katsamba P S, Navratilova I, Calderon-Cacia M, et al. Kinetic analysis of a high-affinity antibody/antigen interaction performed by multiple Biacore users. Anal Biochem, 2006, 352: 208 - 221[doi]

8 Quinn J, Patel P, Fitzpatrick B, et al. The use of regenerable, affinity ligand-based surfaces for immunosensor applications. Biosens Bioelectron, 1999, 14: 587-595[doi]

9 Quinn J G, O'Kennedy R. Biosensor-based estimation of kinetic and equilibrium constants. Anal Biochem, 2001, 290: 36-46[doi]

10 Watts H J, Lowe C R, Pollard-Knight D V. Optical biosensor for monitoring microbial cells. Anal Chem, 1994, 66: 2465-2470[doi]

11 O'Kennedy R, Quinn J G. Detection of whole cell: antibody interactions using Biacore's SPR technology. Bia J, 2001, 1: 22-24

12 Quinn J G, O'Kennedy R, Smyth M, et al. Detection of blood group antigens utilising immobilised antibodies and surface plasmon resonance. J Immunol Methods, 1997, 206: 87-96[doi]

13 Leonard P, Hearty S, Quinn J, et al. A generic approach for the detection of whole Listeria monocytogenes cells in contaminated samples using surface plasmon resonance. Biosens Bioelectr, 2004, 19: $1331-1335$ [doi]

14 Hearty S, Leonard P, Quinn J, et al. Production, characterisation and potential application of a novel monoclonal antibody for rapid identification of virulent Listeria monocytogenes. J Microbiol Methods, 2006, 66: 294-312[doi]

15 Leonard P, Hearty S, Wyatt G, et al. Development of a surface plasmon resonance-based immunoassay for Listeria monocytogenes. J Food Prot, 2005, 68: 728-735

16 Aggarwal S, Janssen S, Wadkins R M, et al. A combinatorial approach to the selective capture of circulating malignant epithelial cells by peptide ligands. Biomaterials, 2005, 26: 6077-6086[doi]

17 Hans D, Pattnaik P, Bhattacharyya A, et al. Mapping binding residues in the plasmodium vivax domain that binds Duffy antigen during red cell invasion. Mol Microbiol, 2005, 55: 1423-1434[doi]

18 Hardy S A, Dimmock N J. Valency of antibody binding to enveloped virus particles as determined by surface plasmon resonance. J Virol, 2003, 77: 1649-1652

19 Li B X, Chen J, Long M. Measuring binding kinetics of surface-bound molecules using surface plasmon resonance technique. Anal Biochem, 2008, 377: 195-201[doi]
20 Daniels G L, Fletcher A, Garratty G, et al. Blood group terminology 2004: From the International Society of Blood Transfusion Committee on terminology for red cell surface antigens. Vox Sanguins, 2004, 87(4): 304-316[doi]

21 Dumaswala U J, Dumaswala R U, Levin D S, et al. Improved red blood cell preservation correlates with decreased loss of bands 3, 41, acetylcholinestrase, and lipids in microvesicles. Blood, 1996, 87: $1612-1616$

22 Dumaswala U J, Wilson M J, Jose T, et al. Glutamine- and phosphate-containing hypotonic storage media better maintain erythrocyte membrane physical properties. Blood, 1996, 88: 697-704

23 Yao $\mathrm{C} \mathrm{Z}$, Zha Z G. Effects of incubation $\mathrm{pH}$ on the membrane deformation of a single living human red blood cell. Curr Appl Phys, 2007, 7: 11-14[doi]

24 Biacore. BIAapplication Handbook. Version AB, 1998

25 Myszka D G, Morton T A, Doyle M L, et al. Kinetic analysis of a protein antigen-antibody interaction limited by mass transport on an optical biosensor. Biophys Chem, 1997, 64: 127-137[doi]

26 Pharmacia Biosensor, Biomolecular interaction analysis with cells and vesicles. NIA Techonology Note 105, Pharmacia Biosensor AB, 1995

27 Myszka D G, He X, Dembo M, et al. Extending the range of rate constants available from BIACORE: interpreting mass transport-influenced binding data. Biophys J, 1998, 75: 583-594

28 Sigmundsson K, Masson G, Rice R, et al. Determination of active concentrations and association and dissociation rate constants of interacting biomolecules: An analytical solution to the theory for kinetic and mass transport limitations in biosensor technology and its experimental verification. Biochemistry, 2002, 41: 8263-8276[doi]

29 Piper J W, Swerlick R A, Zhu C. Determining force dependence of two-dimensional receptor-ligand binding affinity by centrifugation. Biophys J, 1998, 74: 492-513

30 Li P, Selvaraj P, Zhu C. Analysis of competition binding between soluble and membrane-bound ligands for cell surface receptors. Biophys J, 1999, 77: 3394-3406

31 Chesla S E, Selvaraj P, Zhu C. Measuring two-dimensional receptor-ligand binding kinetics by micropipette. Biophys J, 1998, 75: $1553-1572$

32 Long M, Goldsmith H L, Tees D F J, et al. Probabilistic modeling of shear-induced formation and breakage of doublets cross-linked by receptor-ligand bonds. Biophys J, 1999, 76: 1112-1128

33 Long M, Zhao H, Huang K S, et al. Kinetic measurements of cell surface E-selectin/carbohydrate ligand interactions. Ann Biomed Engi, 2001, 29: 935-946[doi]

34 Zhu C, Long M, Chesla S E, et al. Measuring receptor/ligand interaction at the single bond level: Experimental and interpretive issues. Ann Biomed Eng, 2002, 30: 305-314[doi]

35 Huang J, Chen J, Chesla S E, et al. Quantifying the effects of molecular orientation and length on two-dimensional receptor-ligand binding kinetics. J Biol Chem, 2004, 279: 44915-44923[doi]

36 Wu L, Xiao B T, Jia X L, et al. Impacts of carrier stiffness and microtopology on 2D kinetics of P-selectin-PSGL-1 interactions. J Biol Chem, 2007, 282: 9846-9854[doi]

37 McQuarrie D A, Jachimowski C J, Russell M E. Kinetics of small systems II. J Chem Phys, 1964, 40: 2914-2922[doi]

38 McQuarrie D A. Kinetics of small systems I. J Chem Phys, 1963, 38: 433-436[doi] 